\title{
Multiculturalism in Raj Novel: Rereading Paul Scott's The Jewel in the Crown
}

\section{Bhaskar Chettri ${ }^{1} \&$ Dhananjay Tripathi ${ }^{2}$}

\author{
${ }^{1}$ Research Scholar, Department of Humanities and Social Sciences, National Institute of \\ Technology Sikkim, Orcid Id:oooo-ooo2-1826-3074.phen16o16@nitsikkim.ac.in \\ ${ }^{2}$ Assistant Professor, Department of Humanities and Social Sciences, National Institute of \\ Technology Sikkim, Orcid Id: oooo-ooo3-0718-1898. dhananjaystripathig@nitsikkim.ac.in
}

First published September 30, 2019

\begin{abstract}
Paul Scott's The Jewel in the Crown (1966) is analyzed in the light of multiculturalism, considering different aspects of oriental study, the response to hegemonic belief and the question of the subaltern. Scott traces the essence of understanding among different individuals in the Raj era, missed by many writers writing of that tumultuous phase in Indian history. Aiming at the unification of the binaries, he depicts real picture of India presenting human life in extraordinary situations and comments on the shared experiences of different characters. He traces multiculturalism in the period that witnessed steady growth and evolution of ideas revolving around modernism, colonialism, postmodernism, postcolonialism and nationalism. The cultural mosaic of India is presented in the novel by examining the politics of difference and the politics of recognition. After a long time when the novel is read in the context of colonial and postcolonial study, the present paper attempts to highlight nuances of multiculturalism, where unity is aimed between the East and the West.
\end{abstract}

Keywords: multiculturalism, orientalism, postcolonialism, Raj novel, Paul Scott

\section{Introduction}

The Raj era, a landmark period in the Indian history shaped the social, political, economic and cultural identity of the individual immersed in that tumultuous phase. This period witnessed the steady growth and evolution of the making of ideas revolving around modernism, colonialism, postmodernism, postcolonialism and nationalism. However, the clutches of respective identities entrapped writers representing either the colonizer or the colonized and were engaged in "remapping reality in more than one way" (Jain, 2010). Amidst the canvas of colonial and postcolonial literature, Paul Scott traces thinking into multiculturalism in The Jewel in the Crown (1966). After a long period when this novel is read in the context of colonial and postcolonial study, the present paper seeks to examine it, in the light of multiculturalism, addressing different aspects of oriental study, the response to hegemonic belief and the question of the subaltern. The newness of the novel resides in its literary representation of a new strategy where binary opposition is challenged, questioned and a working pattern is evolved.

(c) AesthetixMS 2019. This Open Access article is published under a Creative Commons Attribution Non-Commercial 4.0 International License (http://creativecommons.org/licenses/by-nc/4.o/), which permits non-commercial re-use, distribution, and reproduction in any medium, provided the original work is properly cited. For citation use the DOI. For commercial re-use, please contact editor@rupkatha.com. 
Multiculturalism an encumbered late twentieth century term, complex in itself has engaged readers and scholars across disciplines. It transcends boundaries, where researchers and social scientists are engaged in defining and redefining its relationship with other ism's that studies individual and society as a whole. The debate on the relationship between multiculturalism and orientalism has been a regular phenomenon among scholars in the recent past. Many suggested multiculturalism "a critique of orientalism" (Runnymede, 1997), while some charged it for "legitimating forms of essentialism" (Malik, 1996, Kundnani, 2002) and imperialism (Brown, 2006). Edward Said himself was thrilled to learn that his idea of orientalism emphasized "the actualities of what was later to be called multiculturalism, rather than xenophobia and aggressive, race-oriented nationalism" (2003, p. 336). Nevertheless, one is astonished thinking multiculturalism at par with Said's representation of the East in meticulous contrast to the West. This is why Zaki Nahaboo categorically notes, "multiculturalism ostensibly challenges orientalism" and "reveals the potential and limits of multiculturalism as a site for disentangling political subjectivity from orientalism" (2012).

There has always been a sharp cultural dichotomy between the East and the West, and very often the East is considered as subordinate to the West. To challenge this assumption, there are re-orientalist's notion that "sets up alternative metanarratives of its own in order to articulate eastern identities, simultaneously deconstructing and reinforcing Orientalism" (Mendes and Lau 2014, p. 2). Ideas that once defined "identity formation" in relation to "national and cultural attachment" (Ropero and Alvarez, 2011, p. 93) no longer hold prominence and it is almost impossible to designate markers to a specific location, where different factors contribute in the making of individual's trait and personality. In the complex globalised society, multiculturalism designates the situation of accommodation "where differences are not eliminated but to some extent recognized" (Modood, 2010).

\section{Raj Novel: A reflection of the Raj era}

A flood of colonial writers streamed when imperialism reached its zenith, justifying the colonial rule. Elleke Boehmer in her book Colonial and Postcolonial Literature, writes, "at the time of high imperialism in the late nineteenth century, most British imperialists cherished an unambiguously heroic image of themselves as conquerors and civilizers of the world (1995, p. 23). Imperialism became "a religious and ethical theory and an integral part of a cosmology" (Nandy, 1982), and writers like Kipling, a through advocate of imperialism "justified the dominance of Anglo-Saxon in the name of imperial enterprise" (Ashcroft, Gareth and Tiffin 2000, p. 198). Paul Scott who had a firsthand experience of India and the Raj era presented things as it were and commented as an audience, instead of talking any official stand. Almost all his novels are set in India, but among all The Jewel in the Crown is a masterpiece that advocates multicultural vision in the heyday of nationalism. The Raj era derived new dimensions through his presentation of real life situation and The Jewel in the Crown was immediately succeeded by his three other novels, The Day of the Scorpion (1968), The Towers of Silence (1971), and A Division of Spoils (1975) which is together referred to as the Raj Quartet. Scott engages his readers as "participants in an exploration not only of the British in India, but of humanness itself" (Haswell, 2002, p. 4). He is distinctly clear in his approach with the ideals of the Raj and delves a distinct path much different to Rudyard Kipling and E. M. Forster. He is the first British writer who does not designate label to the characters and "presented the events of the turbulent years between 1942 and 1947 with commendable honesty" 
(Bose, 1990, p. vii). He records the love, fear, sympathy, and hatred that contributed to the development of personality, which in turn affected the course of history.

\section{Situating multiculturalism in The Jewel in the Crown}

The paper attempts to launch an investigative study of multiculturalism in The Jewel in the Crown where Scott adopts a thoroughly new approach in addressing the colonizer and the colonized in the height of nationalist movement. Writers so far writing of the Raj era have missed the essence of understanding among the people living in India irrespective of race, class, caste and gender. Multiculturalism in literature exposed the voice of minorities and multiculturalists "remained reformers not transformers" (McDonald, 2011), and Scott is one such reformer who aims at the unification of the binaries. In the historical backdrop of Indian freedom struggle, he depicts the real picture of India presenting human life in extraordinary situations and shows the relation between the British and the Indian people. The Empire does not hold a "singular perspective" as it has "many voices for whom the first world is only one oppressor" (Barkan, 1994) and Scott engages into a rereading of the Raj era highlighting different attributes that make up a multicultural society. For Scott, the political and economic factor is far less relevant than the social factor and instead of why and how, he is concerned of what happened in the Raj era.

He addresses the love that existed among the Hindus, Muslims, Indian, British and the Eurasians and represents a new India engulfed in the trauma of Second World War and ignited in the wake of freedom struggle. Scott "placed his characters in various relationships to their environment, to each other, and ultimately to the reader" (Haswell, 2002, p. 65) and presents personal connections that stands as the hallmark of a society. Scott in the opening page of his novel writes;

This is the story of a rape, of the events that led up to it and followed it and of the place in which it happened. There are the action, the people, and the place; all of which are interrelated but in their totality incommunicable in isolation from the moral continuum of human affairs. (Scott, 2005, p. 1)

But the novel is much more than the story of a rape. It assesses the nuances of human relationships transcending the periphery of conflicts and divisions, a propagates a universal humanitarian outlook. Weinbaum beautifully describes the novel as "panoramic in scope and microscopic in detail, the book recreates the events, sights, sounds and smells of British India in the 1940's" (1978, p. 100). It is fascinating to study about India, a home to different cultures, languages, religions and communities and Scott does this enthusiastically who knew that the acknowledgement of differences marks the trait of being an Indian. He delves into,

the relationship of the private lives of the individuals to history; the relativity of what we know as 'truth'; the epistemological question - the difficulty of arriving at truth; the isolation of individuals; the relation of a man's life to his vocation or career; the lost childhood and the quest for paradise.(Rubin, 1986, p. iii)

Orville Prescott in his 1966 review of The Jewel in the Crown wrote, "It may be one of the finest novels about India since E.M. Forsters's A Passage to India" (quoted in Weinbaum, 1978). Jacqueline Banerjee rightly says about the novel,

It is time now to see it not simply as a major work about the end of the empire, but also, and much more importantly, as an exploration of the greatest problem we face today how best to live our lives in a multicultural world. (2009, p. 83) 
We are introduced to Miss Edwina Crane in the first chapter itself who "had lived in India for thirty five of her fifty seven years" (Scott, 2005, p. 6). She represents the British subaltern who travelled to India after the death of her father as a travelling nurse companion. Almost all AngloIndian texts so far dealt with the experiences of the British upper class, their thrilling experiences and the legacy of the crown. However, The Jewel in the Crown is a novel with a difference, it engages in the analysis of characters representing the bottom strata of the society, instead of discussing the effluent lots.

Miss Edwina Crane represents the colonizer but she is herself a subject of the colonial system. Her position in Britain as well as in India is not equivalent to the ruling class and there is a stiff difference between Edwina and other British characters in the novel. In doing so, Paul Scott though termed as the "chronicler of the raj nostalgia" (Rushdie, 1985) is inadvertently positioning a postcolonial stand. However, he cannot be termed a postcolonial writer as he represents the colonial class. His characters are through and through individuals and all distinct in types. No two characters can be placed under an umbrella; his work thoroughly bears testimony to multiculturalism that addresses voices of varied kind.

It is Edwina, who in the course of action becomes a missionary teacher, sets the tone in the novel in maintaining a bridge between imperialism to multiculturalism. She is an ardent supporter of India and strongly believes that "India must be independent. When the war's over, we've got to give up her" (Scott, 2005, p. 26). She voices the harmony and oneness in human nature, which can excel through the fragments of culture, race and religion, rising in sublime and lofty feelings of human and humanism. She is happy to work in India for the mission and believes that it is through her engagement with the mission that she "acquired an admiration for the Indians through love and respect for their children" (Scott, 2005, p. 3). Miss Crane though familiar with many uprisings in India is always afraid of one and "the only hope for the country she loved lay in the coming together at last of its population and its rulers as equal partners" (Scott, 2005, p. 41).

The scope of Indo-British relationship through personal connections and individual qualities finds new vista in the novel. This is initiated with the ever-lasting relationship of Edwina Crane and Mr. Chaudhari, the teacher in the Dibrapur School. Class, race, nationality and religion do not in any way shape their relationship, instead circumstances strengthen their relationship and they are committed to serious sacrifices. Mr. Chaudhari is a different personality in contrast to his wife who is old-fashioned. He is sophisticated and westernized and prefers to wear foreign clothes at least in the company of Miss Crane. The day of the riot marks an important chapter in the life of Miss Crane as well as in the life of Mr. Chaudhuri. They hurriedly handover the children to their parents, after they were informed of the riot and Miss Crane decides to return back to Mayapore. Mr. Chaudhuri requests her to stay back but she insists to return, so he accompanies her thinking that she will be safe in the company of an Indian. He leaves his wife back and proceeds to Mayapore, but they meet a gang of rioters in the way. The rioters were surprised to see Mr. Chaudhuri in the company of an English woman and label him as a traitor. They stood in the middle of the road to block the way. Mr. Chaudhuri tells Miss Crane to keep going crashing the rioters but she couldn't. "She tightened her mouth preparing to obey, but failed. She couldn't drive into a mass of living creatures" (Scott, 2005, p. 63). The rioters in turn smashed Miss Crane into the drain and kill Mr. Chudhuri.

The image of Edwina Crane holding the hand of dead Chaudhuri after the riot speaks volume about the kind of relationship they share. When all the rules of the society fail, it is the humanity that speaks up and lends direction. Edwina Crane and Mr. Chaudhari may be strong 
opponents in the pages of history book but when it comes to human affairs, they are equal and one. She was so close to Mr. Chaudhuri that her taste of music was also similar to him and "the only music she ever listened to when with the Chaudhuris was Indian Classical music" (Scott, 2005, p. 49). Our contemporary reading of the novel, written in the neocolonial period about colonial India has many things to offer, it lends direction to engage and adjust in a society that is no more homogeneous.

The development of love affair between Daphna Manners, the English girl staying in India and Hari Kumar, an Indian who has acquired English education also marks the multicultural element in the novel. They hail from different backgrounds, they know their position and status in the society, yet they make an effort to relate as humans. The novel captures the ethos and echoes of the Raj era, and come up with new possibilities and new dimensions. This is why Crane writes,

Scott...as many earlier Anglo-Indian writers had certainly done, is concerned primarily in the Raj Quartet with what might usefully be termed the 'Index of Whiteness' that operates within Anglo-Indian society, and indeed British society as a whole, and necessarily inflects the relationship between British men and women in India and Indians. (Crane, 2004, p. 19)

They started with friendship and ended in love with a conscious frame of mind. Daphna is happy when their friendship blossoms into love and feels that they have attained a much-needed unification of races. However, their relationship is short lived, it dies premature. Though they do not contribute to its death, the external factors led to the death of their transcendent togetherness. Daphna Manners is raped by a gang of Indian youth in the night of 9 August 1942 and later, Hari is arrested by Ronald Merrick on the charges of rape. Many questioned Scott why there is the rape of an English girl; instead it should be the rape of an Indian girl that metaphorically describes the rape of India by the British. Some commented that the "assault in the Bibhigarh Gardens is an attack on humanity, by those who lack the slightest respect for it. (Banerjee, 2009, p. 80). The issue is further complicated after the rape and the struggle of Hari begins from the Bibhigarh incident. He is asked to remain silent by Daphna and he does so but his silence lends him into serious conflict and he has to face terrible consequences. The feedback offered by Daphna herself in the interrogation lends a new direction and the Indo-British relation is questioned at its core. The incident gathered so much focus that the novel is considered more a story of rape while it is an examination of the Raj era that redefines orientalism, postcolonialism and multiculturalism.

Hari finds himself in a no man's land when he had to return to India after the death of his father. His British education failed to find his lost self and "Hari can be seen not only as a modern anti-hero caught in a paradox, but also - again with regard to the raj discourse - as an angry retort to Rudyard Kipling's most popular creation" (Bachmann, 1997, p. 238). He can speak English more fluently than an Englishman can, but he cannot speak Indian language. This resulted in the loss of his self; he is in a dilemma about his identity. The British education that he hoped would rescue him at the hour of crisis, lends him into one. He laments when his friend Colon does not recognize him, "I am invisible not only to white people because they are white and I am black but invisible to my white friend because he can no longer distinguish me in crowd" (Scott 1995, 300). Hari is not a mimic character of Naipaul but a hybrid character of Bhaba who has inherited both Indian and British qualities. Hari though seems British, could not represent the British but failed to be an Indian too. His love with Daphna suggests the possibility of the union between the East and the West and they celebrate difference cutting across the boundaries of race, class, culture and language. 
Multiculturalism is often anticipated to be a utopian idea but it is not, it is an amalgamation of everything that makes a society. There are multicultural conflicts and tussles but there is always an aim for recognition to all the traits that define and make up an identity. Ronald Merrick a district police represents the colonial class but he too does not come from the ruling class. He represents rigid imperialistic values and is always conscious of his racial superiority. Scott writes,

The affair that began on the evening of August $9^{\text {th }}, 1942$, in Mayapore, ended with the spectacle of two nations in violent oppositions, not for the first time nor as yet for the last because they were then still locked in an imperial embrace of such long standing and subtlety it was no longer possible for them to know whether they hated or love one another, or what it was that held them together and seemed to have confused the image of their separate destinies. (Scott, 2005, p. 1-2)

Ronald is always engaged in proving his British identity and justifying the colonial legacy. He knows his boundaries and he constructs such boundaries for his Indian counter parts as well. He holds an orientalist approach to India and Indians and the hegemonic notion of the West is latent in him. This however cannot be termed a critique on colonialism, as the novel also questions the imperialistic values, actions and the reactions of the colonized counterparts. His singular treatment to the subaltern lends them an opportunity to be one and equal among all. Therefore, a "convivial culture" (Ropero and Alvarez, 2011) emerges out that marks the dormant ideas of multiculturalism in the novel.

The rich tradition and culture of India captivates even those who are not part of India. Mrs. Ludmila Smith and Doctor Anna Klaus contribute in sharing the positive energy with the hungry and the sick. The origins of Ludmila were obscure, "some said she was related to the Romanovs; others that she had been a Hungarian peasant, a Russian spy, a German adventuress, a run-away French novice" (Scott 2005, p. 127). Ludmila Smith distributes money to the beggars and feeds the hungry while Doctor Klaus is touched by the tragedies that she witnesses in the hospital. They treat the Indian characters as equal and they are never proud of their superior position. Like other "women missionaries, they kept themselves apart from politics" (Pass, 2014, p. 183) and worked for the welfare of the needy and the downtrodden. The novel opens a large humanitarian dimension while discussing these non-British, non-Indian women that has remained untouched until Scott. They do not represent the ruling class and they are living as minorities in colonial India. However they are happy sharing moments with any other character. Nothing can tumble their love for India and they feel at home in India, despite being away from their families. Scott shows in the novel that the Raj era is not just the depiction of conflict between the ruler and the ruled. Excessive importance was credited to the ruling class of the society prior to Scott but Scott shifted gears and focused on the common characters in the society. Society does not run on formula, there may be rules governing different aspects but the individuals have their own perception, action and reaction that govern the functioning of a society. Scott is watchful about the society he is commenting and he minutely traces the role of every individual in the making of a society.

Shalini Gupta-Sen, the aunt of Hari Kumar is very sensitive and open to the problem of other characters. She is happy to invite Daphna Manners to her house and she does not care whether Daphna is Indian or British. She learnt the English language from her brother and she regards the English language and western values in high esteem. She vehemently rejected the idea of becoming a sati when her husband died and decided to live in her own terms. It is astounding that Shalini Gupta-Sen, being an Indian opposed the idea of sati but later in the course of the 
novel Miss Edwina immolated herself and committed suicide in the form of sati. We wonder why Edwina committed suicide in the form of sati. Her role in providing evidence about the attackers of Mr. Chaudhuri also lends many dimensions to the novel. She chooses to remain silent on the issue in the manner of Daphna. All her actions open new debates that only strengthen the multicultural element in the novel.

Lili Chatterjee, the proud owner of MacGregor house represents the aristocratic class and asserts her vision "I am not a Hindu but I am an Indian. I don't like violence but I believe in its inevitability" (Scott, 2005, p. 77). She represents the idea of Tariq Modood who asserts that, "A sense of belonging to one's country is necessary to make a success of a multicultural society" (2010, p. 168). She opens the answer to ideas that question how multiculturalism is possible in relation to nationalism. In fact, the idea of nationalism during the final days of colonialism united the nation and directed into multicultural thinking. The idea of democracy, equality and brotherhood fostered the notion of multiculturalism and the British class by now also realized that their stay in India is numbered. They seem ready for the end of imperialism though with a heavy heart. This resulted in the complex mix of the eastern and western values contributing to multicultural values.

The daughter of Daphna Manners, Parvati whom Lili Chatterjee believes to be the daughter of Hari Kumar is the new hope that emerges in the novel, a hope that there could be a cordial union between the British and the Indian. Daphna says;

The child I bear is important to me. Even though I can't be positive it is his. But I think so, I believe so. If it isn't , it is still a child. Its skin may be dark as Hari's or almost as pale as mine, or somewhere in between. But whatever colour - he, or she, is part of my flesh and blood; my own typically ham-fisted offering to the future! (Scott, 2005, p.403)

Parvati is the torchbearer of the new order that seems to be in vogue after the breakdown of the old order in the land. She marks the end of the imperialistic regime and the independence of the country along with the birth of universal humanitarian approach to the individuals. There is a new hope for a new beginning and "it is with this new glimmer of hope for a postcolonial, postracial society that the whole project closes" (Banerjee, 2009, p. 71). She marks that there is no significant difference between the East and the West rather they could be united and grow together without any tussle. Everybody accept Parvati, which shows the acceptance of the union of East and the West. She suggests the oneness of human that cannot be demarcated by the boundaries of religion, culture, class and nationality.

\section{Conclusion: Reading Scott today}

Scott treats all characters as equal in the novel. He is neither a propagandist nor a historian. Sometimes he moulds the presentation of the raj left and right but what is important is his sincerity to human emotions and sentiments. He is much ahead of his time to realize union is the aim, almost all his characters aim for unity with India or with Indians. He never glorifies the white man's burden but silently aspires for the equal recognition of all individuals cutting across boundaries of nation, race, religion and culture. He is hopeful of the unity of the east and the west but nowhere he is didactic, instead he leaves it open to the characters to decide and adorn what best suits them. 
Scott presents the cultural mosaic of India in the Raj era through examination and evaluation of British imperialism. He depicts point of view of different characters analyzing the social and political situations of the period and examines its influence on the native and British people. He is successful in presenting the joy of complex Indo-British relationship, assessing the action and reaction of the characters that affects the course of history. In contrast to other AngloIndian writers who adopt paternalistic attitude to India and Indians, Scott adopts fraternalism initiating a new dimension of studying the orient and orientalism. Multicultural literature is always based on realism concerning race, class and gender and this novel is a careful record of embattled British Empire engulfed in the burgeoning nationalist movement. With the examination of the hitherto unexplored positive Indo-British relationship, Scott though British by citizenship appears to be Indian by memory and values. He found a new theme chronicling the death of the Raj and engages in identity formation; examining the politics of difference and the politics of recognition.

\section{References}

Ashcroft, B, Gareth G and Tiffin H. (2000). Post Colonial Studies, Key Concepts. London: Routledge.

Bachmann, H. (1997). Speaking of the Raj-Language in Paul Scott's The Jewel in the Crown. Journal of the English Association, 46(186), 227-249.

Banerjee, J. (2009). Women of Affairs: Contrasting Images of Empire in Paul Scott's The Raj Quartet. Journal of Commonwealth Literature, 44(3), 69-85.

Barkan, E, (1994). Post-Anti-Colonial Histories: Representing the Other in Imperial Britain. Journal of British Studies, 33(2), 180-203.

Boehmer E. (1995). Colonial and Postcolonial Literature. New York: Oxford University Press.

Bose, S. (1990). Attitudes to Imperialism: Kipling, Forster and Paul Scott. Delhi: Amar Prakashan.

Brown, W. (2006). Regulating Aversion: Tolerance in an age of Diversity. Princeton: Princeton University Press.

Crane, R. J. (2004). Playing the White Man: Ronald Merrick, Whiteness, and Erotic Triangles in Paul Scott's Raj Quartet. Journal of Commonwealth Literature, 39 (1), 19-28.

Haswell, J. (2002). Paul Scott's Philosophy of Place(s): The Fiction of Relationality. Studies in TwentiethCentury British Literature. New York, Frankfurt \& Oxford: Peter Lang.

Jain, J. (2010). From Encounters to Introspection: Negotiating Cultural Pasts. Indian Literature, 54(6), 134141.

Kundnani, A. (2002). The Death of Multiculturalism. Race E Class 43(4), 67-72.

Malik, K. (1996). The Meaning of Race: Race, History and Culture in Western Society. London: MacMillan Press.

McDonald, P. D. (2011). Thinking Interculturally. Interventions: International Journal of Postcolonial Studies, 13(3), 367-385.

Mendes, A. C and Lau, L. (2014). India through re-Orientalist Lenses. Interventions: International Journal of Postcolonial Studies, 17(5), 706-727.

Modood, T. (2010). Multicultural Citizenship and Muslim Politics. Interventions: International Journal of Postcolonial Studies, 12(2), 157-170.

Nahaboo, Z. (2012). Subverting Orientalism: Political Subjectivity in Edmund Burke's India and Liberal Multiculturalism. Citizenship Studies 16(5-6), 587-603. 
9 | Multiculturalism in Raj Novel: Rereading Paul Scott's The Jewel in the Crown

Nandy, A. (1982). The Psychology of Colonialism: Sex, Age, and Ideology in British India. Psychiatry, 45(3), 197-219.

Pass, A. (2014). Swaraj, the Raj, and the British Woman Missionary in India, c. 1917-1950. Transformation, 31 (3), 175-188.

Ropero, L. L. and Alvarez, A. M. (2011). Multiculturalism in a selection of English and Spanish fiction and Artworks. Social Identities, 17(1), 93-104.

Rubin, D. (1986). After the Raj: British Novels of India since 1947. Hanover and London: University Press of New England.

Runnymede, T. (1997). Islamopobia: A Challenge for us all. London: Runnymede Trust.

Rushdie, S. (1985). Outside the Whale. American Film, 10(4), 70-74.

Said, Edward W. (2003). Orientalism. London: Penguin.

Scott P. (2005). The Jewel in the Crown. London: Arrow Books.

Weinbaum F. (1978). Paul Scott's India. Critique: Studies in Contemporary Fiction, 20 (1), 100-110.

Mr. Bhaskar Chettri is a research scholar in the Department of Humanities and Social Sciences, National Institute of Technology Sikkim.

Dr. Dhananjay Tripathi is an Assistant Professor in the Department of Humanities and Social Sciences, National Institute of Technology Sikkim, India. 